\title{
How Britain became an island
}

\author{
Philip Gibbard \\ Cambridge Quaternary, Department of Geography, University of Cambridge, Cambridge, England
}

Island Britain is separated from the European continent by the English Channel and the North Sea. But it was not always so. The floor of the Channel provides evidence for two catastrophic floods arising from the drainage of huge glacial lakes in the area of the southern North Sea. These megafloods carved the Dover Strait to make Britain the island it is today.

This presentation was given as the third in the Second Nature speaker series on Thursday, 27 September 2007 at 18:00 GMT.

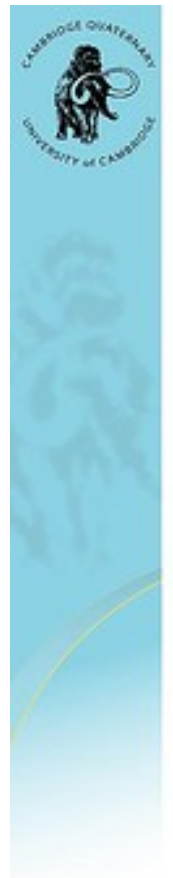

\section{How Britain became an island}

\section{Philip Gibbard}

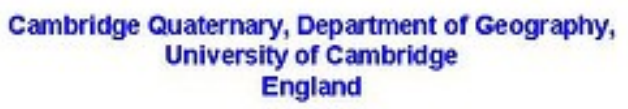

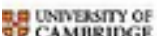

Britain, as everyone knows, is an island surrounded by a 'moat' of water that has historically been so important to our island country's defence. The English Channel and 
North Sea are so much a part of the map that we seldom think about how they formed. So, today I will talk about some of major events that occurred to shape these seaways.

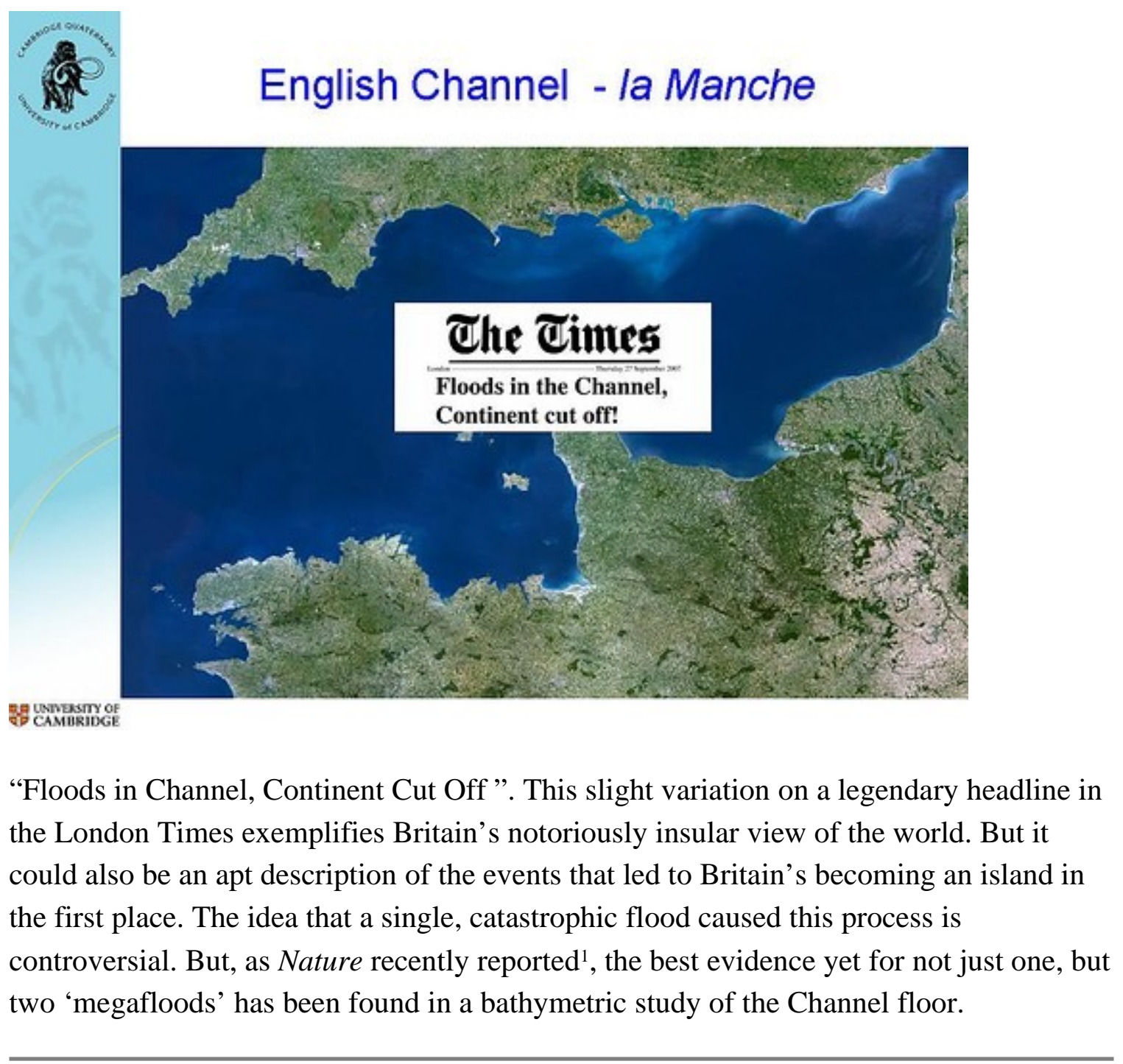




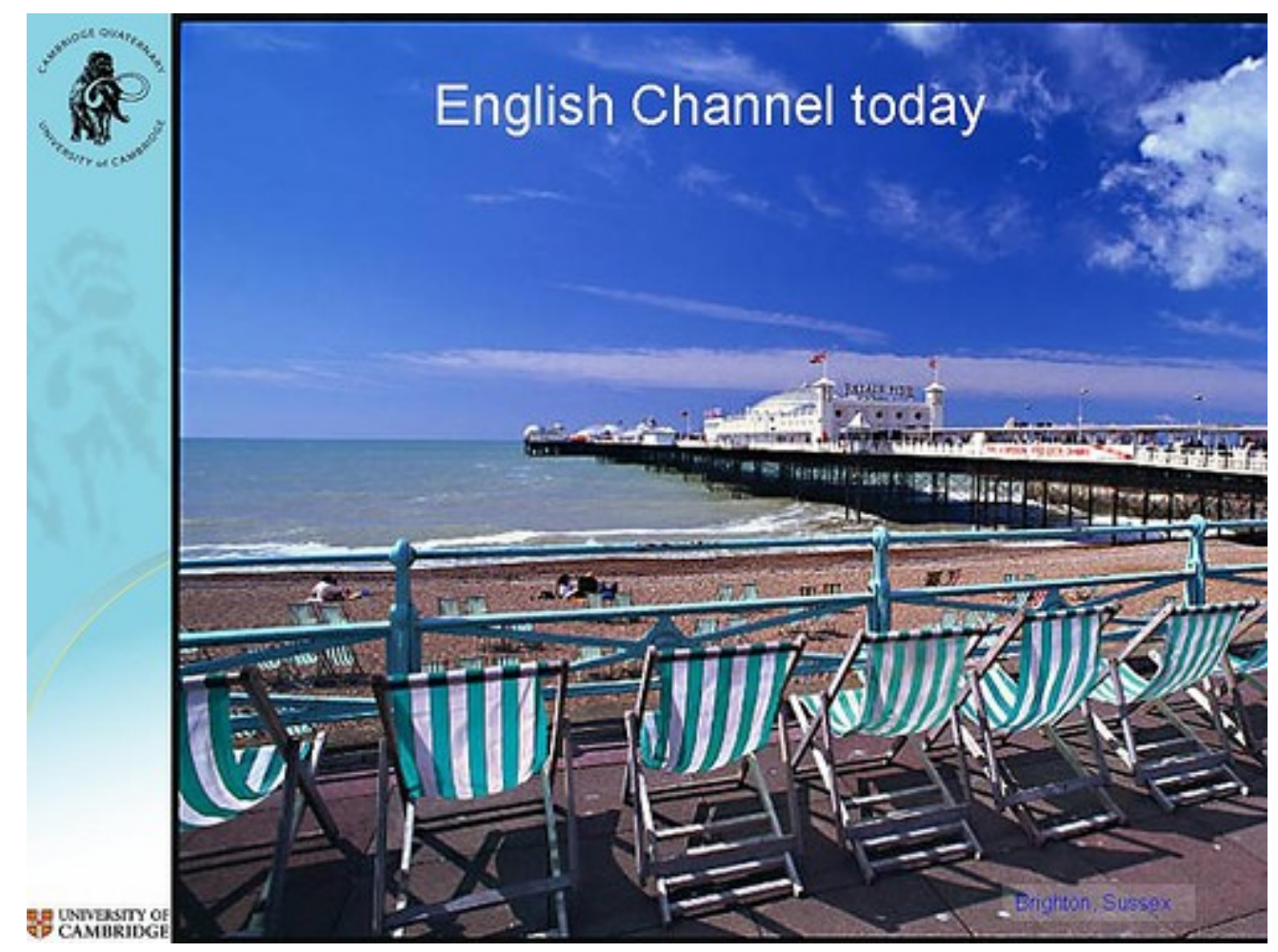

Standing on the southern English coast today, looking at the familiar view of the Channel, or la Manche as the French say, it is difficult to imagine that as little as 20000 years ago the view would have been strikingly different.

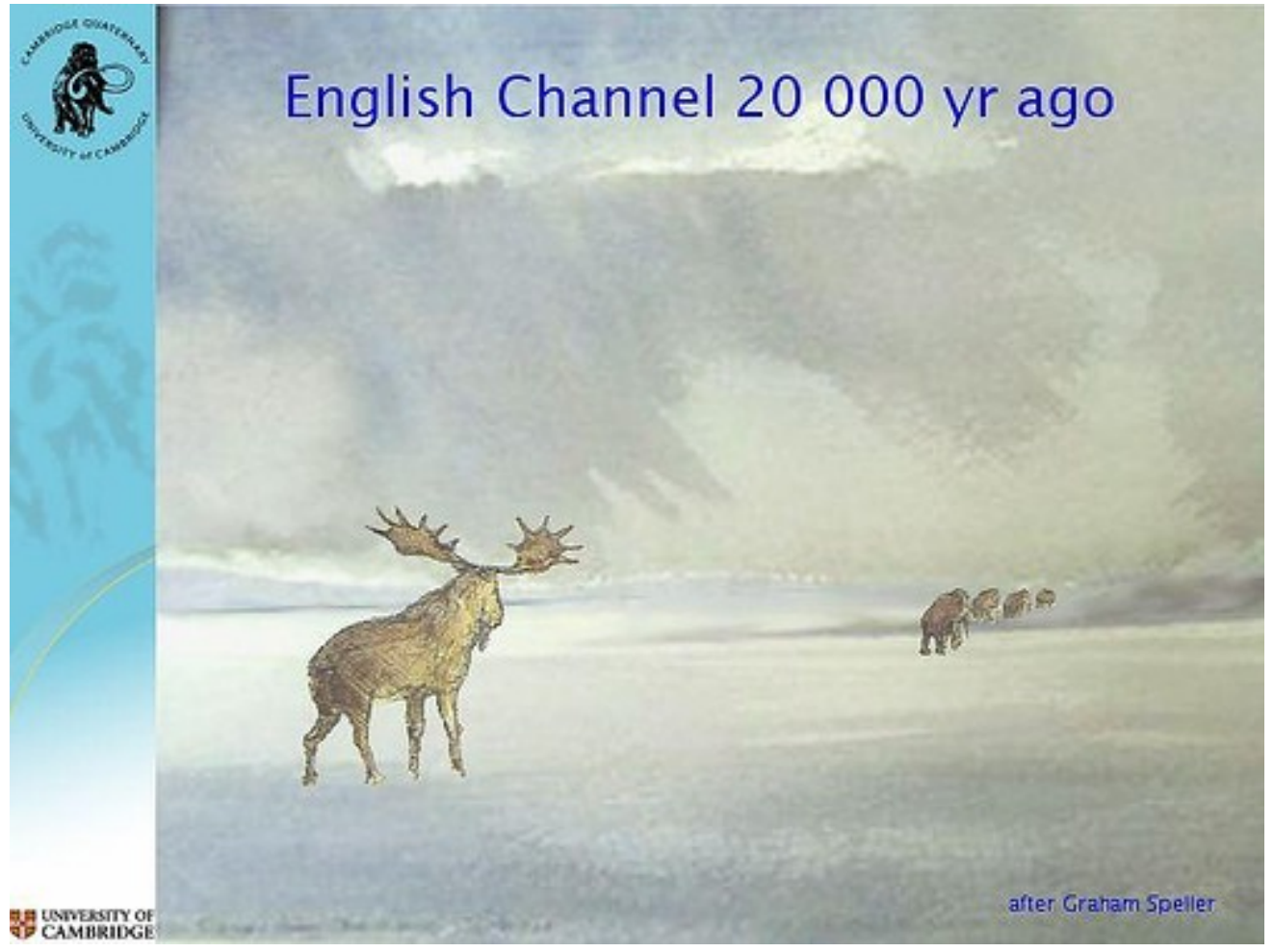


Instead of the sea, you would be confronted by a vast shallow valley, home to mammoths and elks, and possibly from time to time, migrating humans. The valley was drained by a substantial river ${ }^{2,3}$.

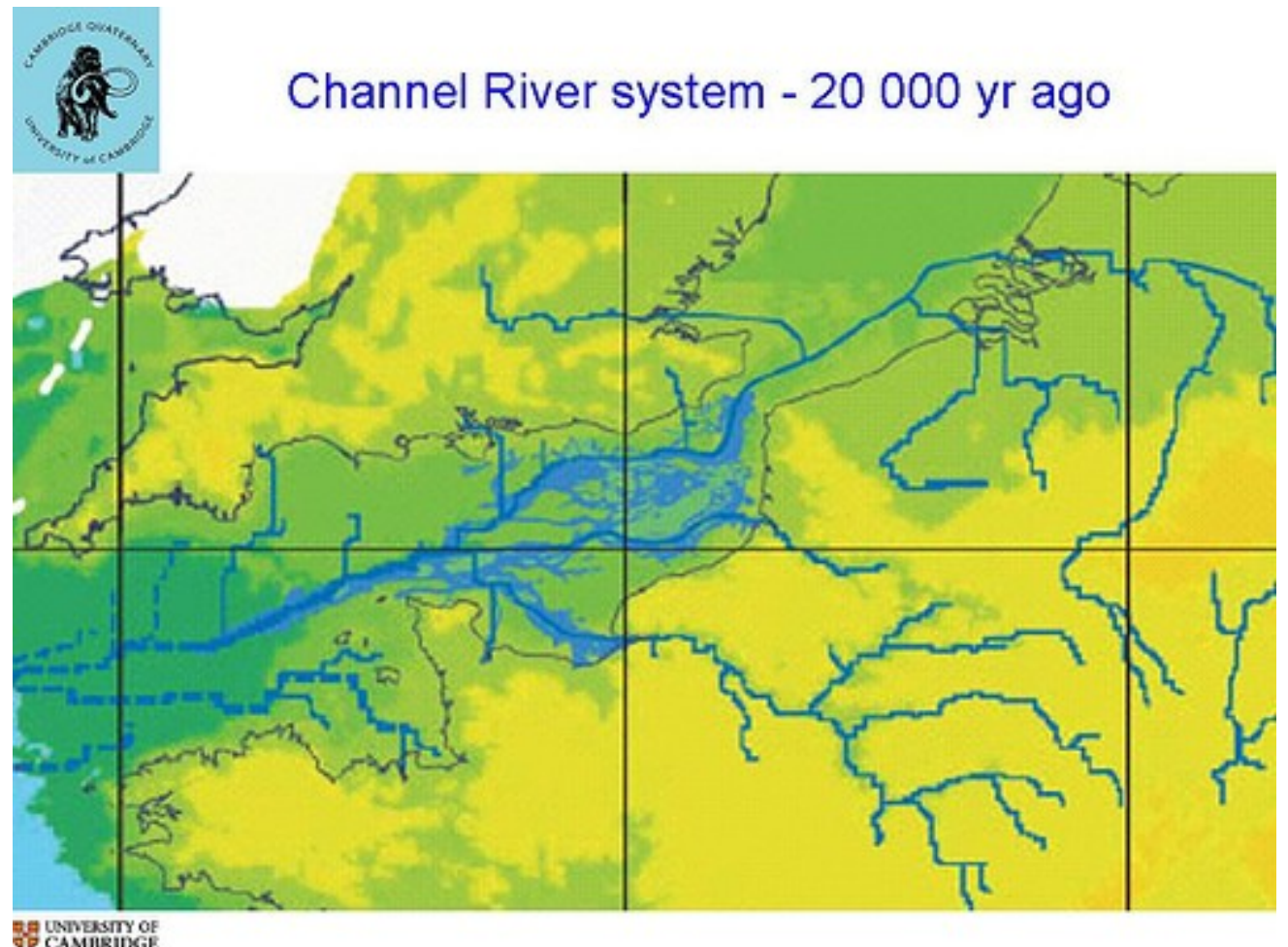

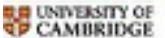

This westward-flowing Channel river was larger than any in Europe today because it carried water, not only from the rivers currently entering the Channel, but also from the southern North Sea, including the Rhine, Meuse, Thames and Scheldt ${ }^{2,3}$. The smooth, shallow, bedrock Channel floor is over $500 \mathrm{~km}$ long and slopes gently from the Dover Strait towards the shelf margin between Brittany and Cornwall. In the central and eastern Channel, this surface is cut by a network of valleys, many of which are continuations of coastal rivers, like the Seine, Somme, Solent and smaller streams ${ }^{4}$.

Throughout the last 2-3 million years, the build up and decay of ice sheets on the continents have driven spectacular changes of global sea-level. 


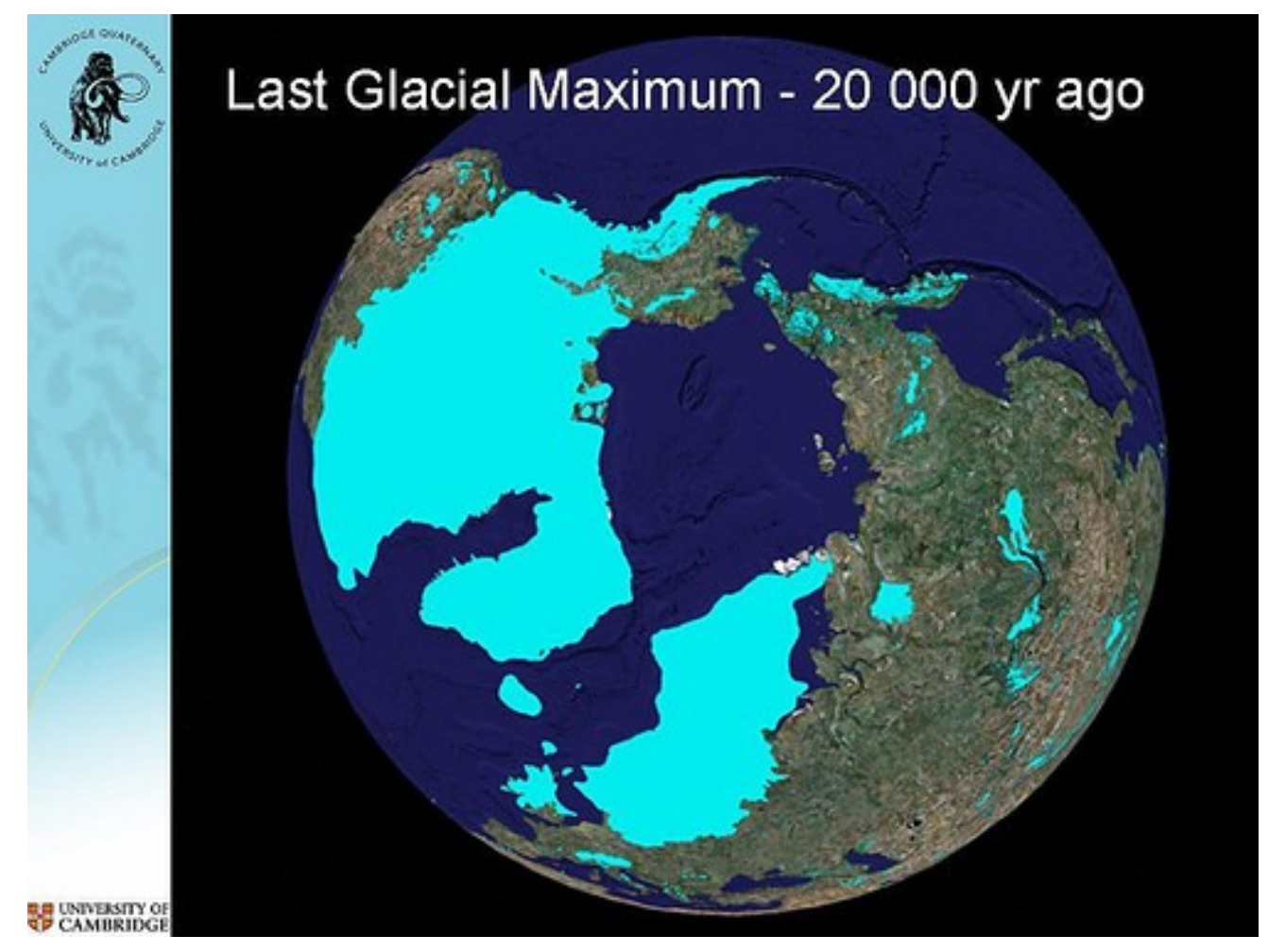

Today we live in a warm interval, a period characterised by limited glaciation and therefore high sea-level. However, for much of the time global sea-level was lower, exposing shallow areas, like the Channel and the North Sea, as dry land, their surfaces indistinguishable from the ground we live on. For example, at the peak of the last glaciation, 20000 years ago, global sea-level stood about $100 \mathrm{~m}$ below that today. Driven by climatic fluctuations, these sea-level changes resulted in cycles of emergence and submergence of the Channel floor. 


\section{The English Channel 600000 yr ago}

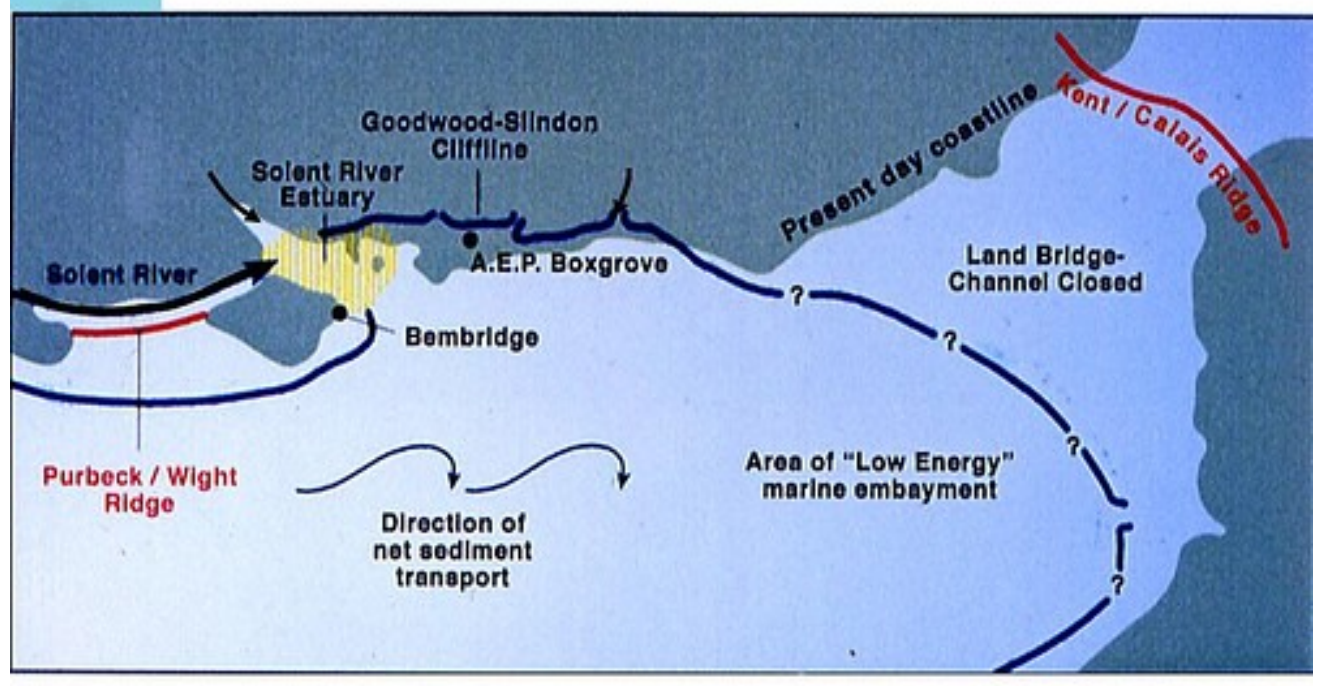

Sag Gavesmy of

after Bates

The Channel has existed for over 50 million years, mainly as a marine embayment. About 600000 years ago, the Channel was flooded, like today, but unlike today there was a substantial land barrier, Weald-Artois ridge, that linked Britain to the European Continent $^{2}$. 


\section{The English Channel 600000 yr ago}

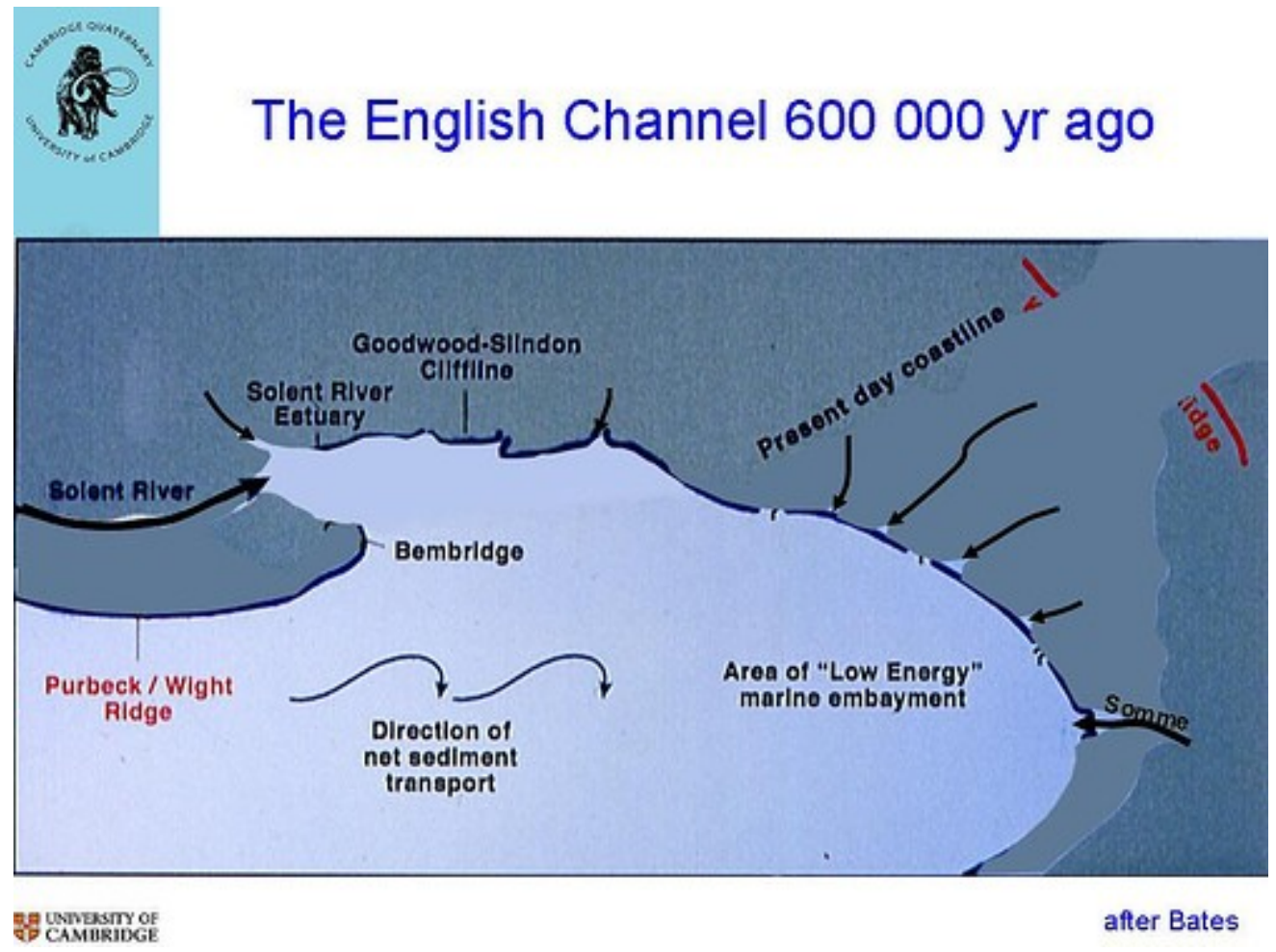

We can see this ridge when we put the landscape back.

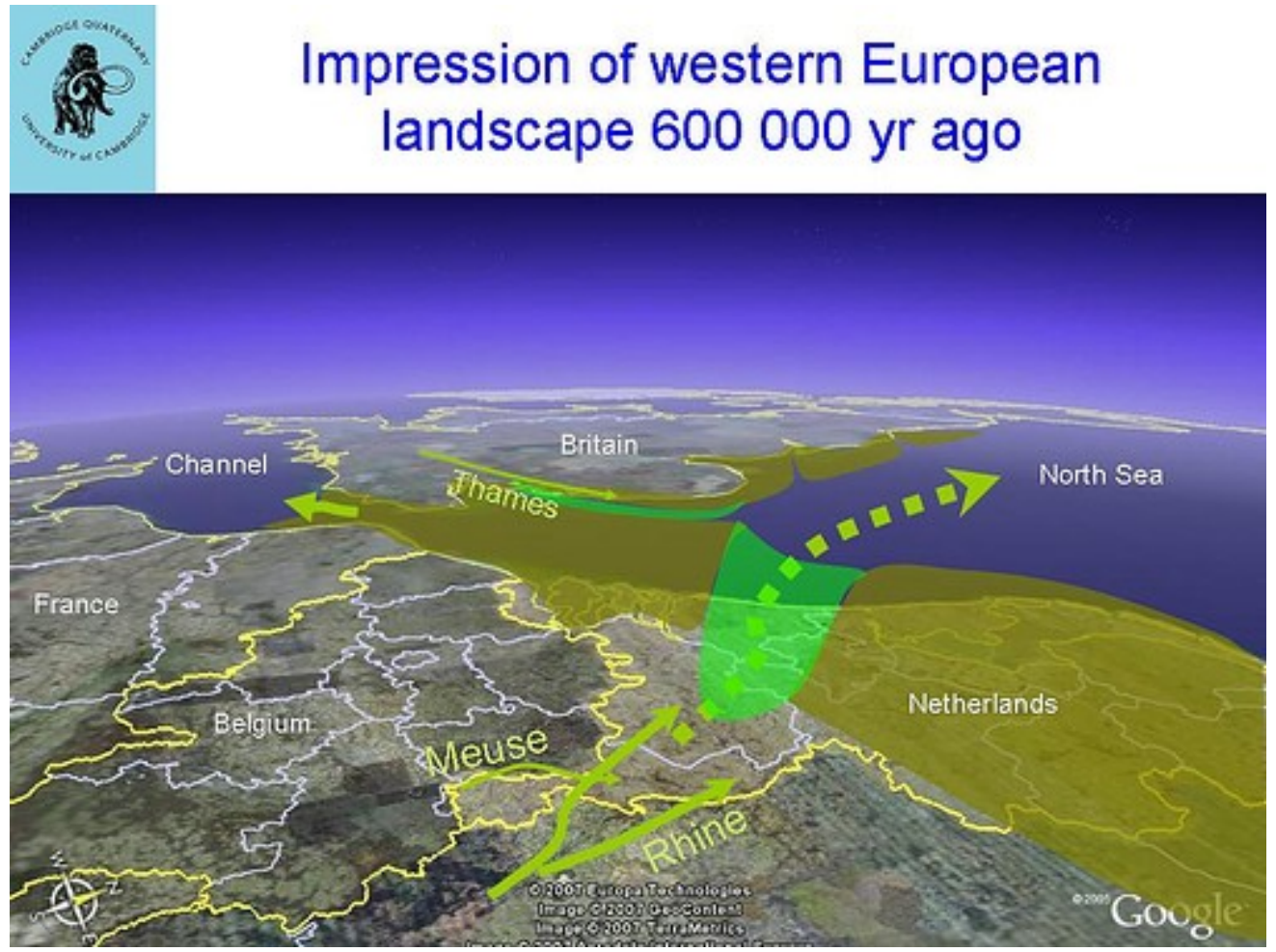


This land area also extended into the southern North Sea and there was a rather different landscape geography, especially with rather different courses of the major rivers, as you can see in this unusual view of the region looking towards the west.

During cold periods up to $500000 \mathrm{yr}$ ago the Channel floor and southern North Sea were drained by separate river systems. The Channel river aligned along the Channel basin's axis drained towards the Atlantic Ocean, as we've seen, whilst in the North Sea the major rivers drained northwards².

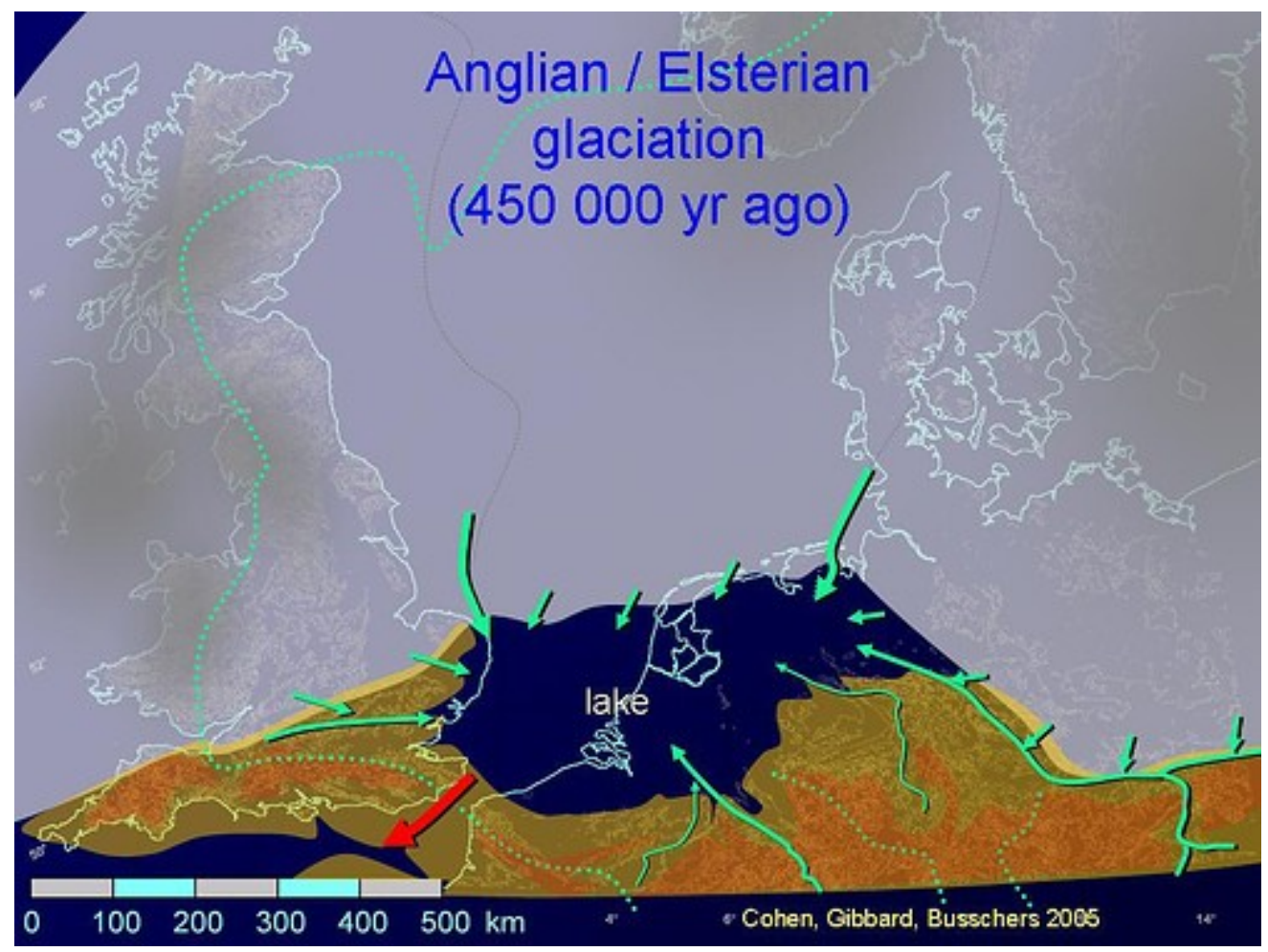

But this is the Ice Age - so what about glaciation? Although there were earlier events, the first major extension of a continental-scale ice sheet into lowland central Europe and Britain occurred about 450000 years ago. This ice advanced across the emergent North Sea floor from the mountains of southern Scandinavia and Scotland, blocking the northwards-flowing rivers and causing an immense glacial lake to develop in the basin south of the ice front. Once dammed, the water that continued from much of western European rivers caused the lake level to rise ${ }^{2,5}$.

Evidence for the lake also comes from sediments from both sides of the North Sea. 


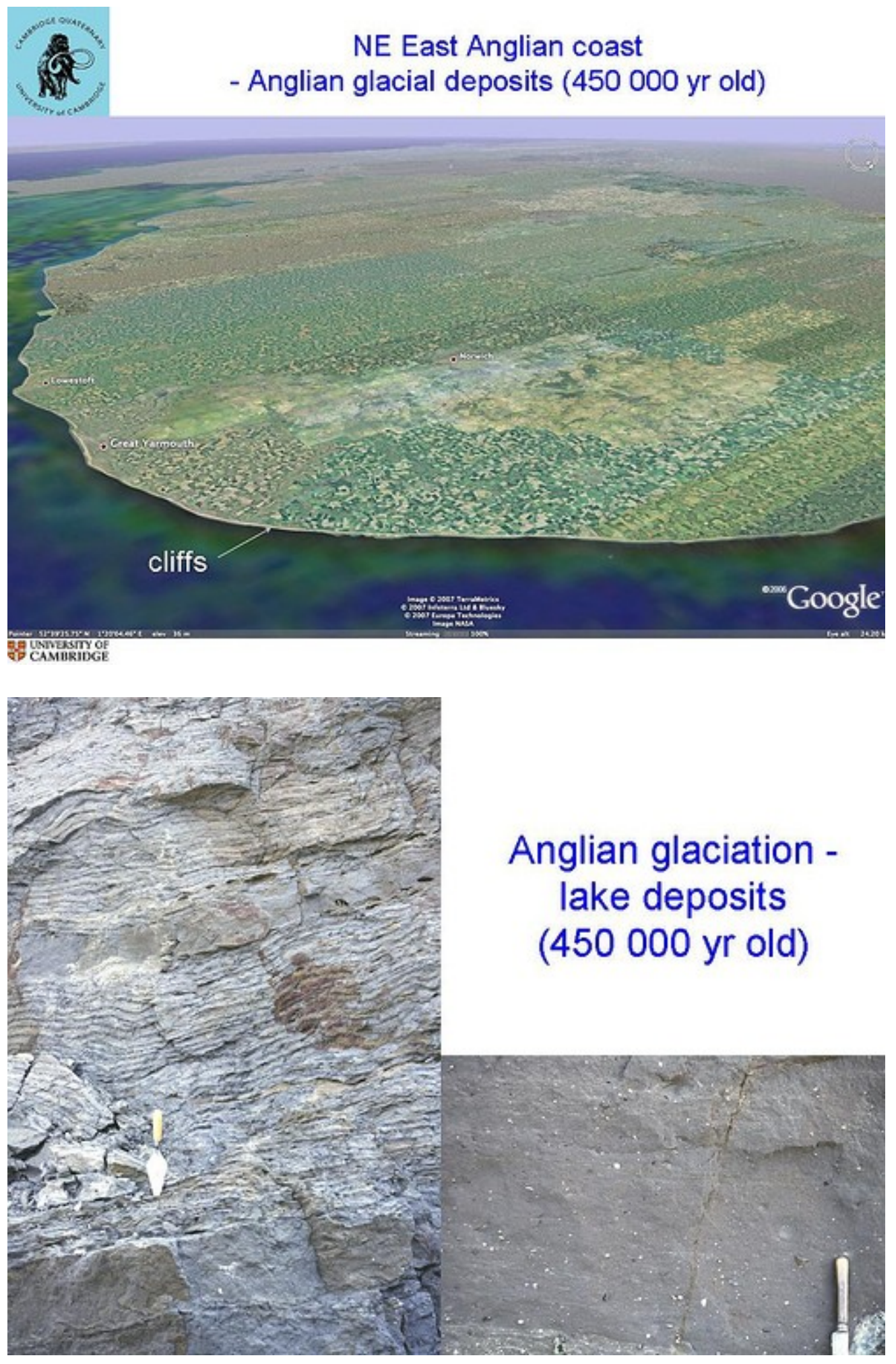

In England, characteristic glacial and glacial-lake sediments can be seen in the substantial cliffed coast of north-eastern East Anglia. 


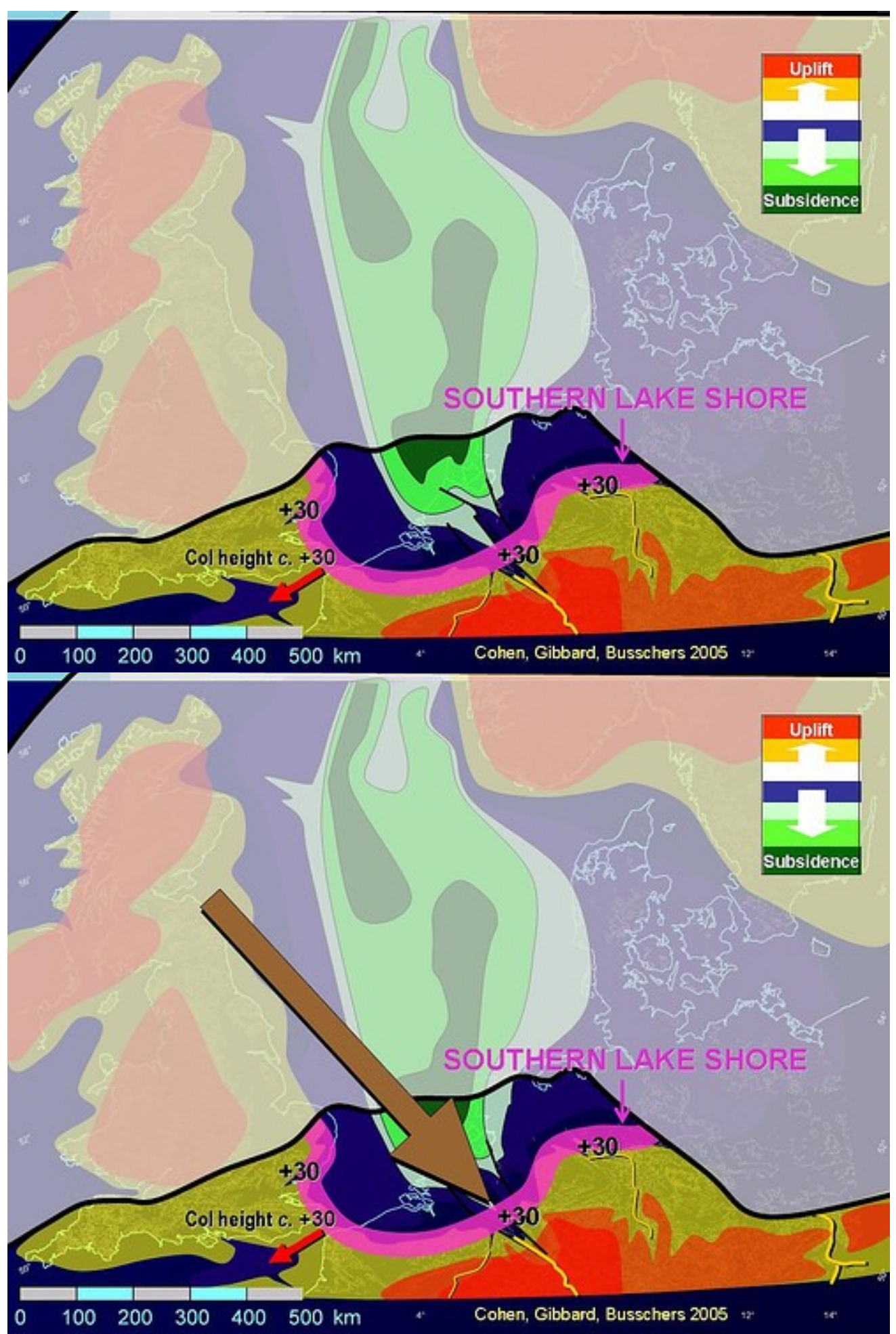

Whilst on the eastern side of the North Sea, in the eastern Netherlands and neighbouring Germany, where the major rivers Rhine and Meuse entered the lake, delta deposits have been found ${ }^{6}$. 


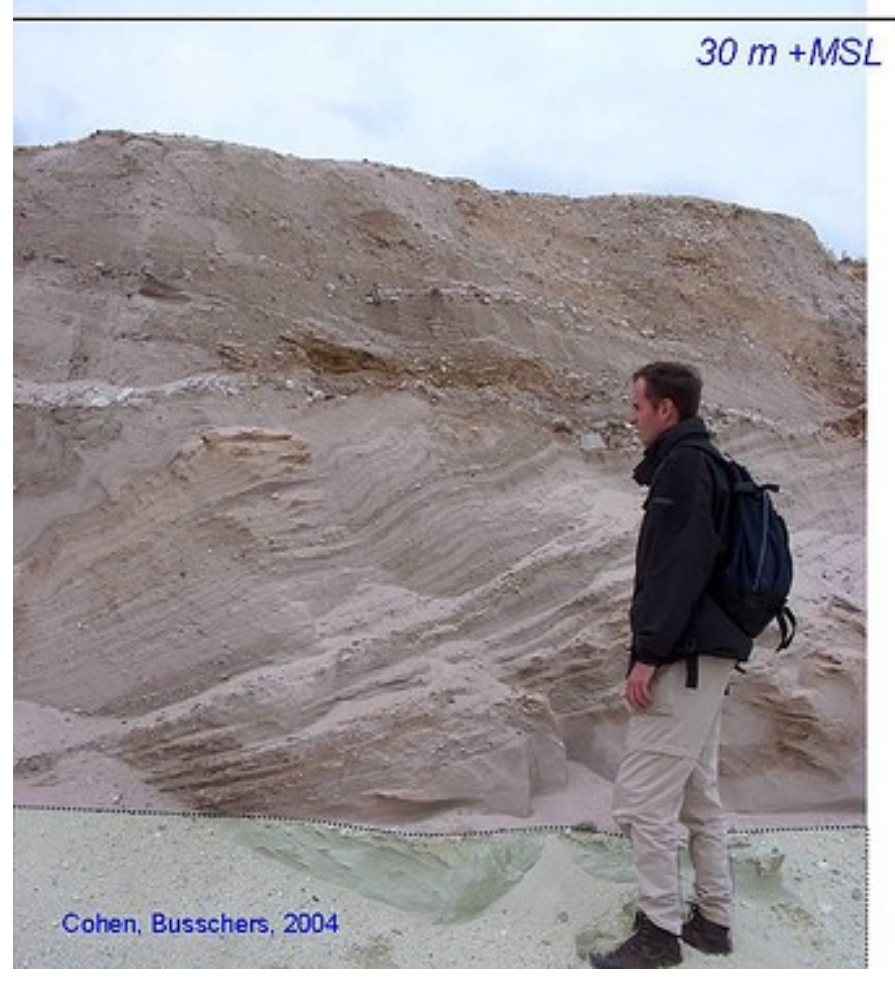

\section{Ht3 terrace \\ Della platiorm}

Delta sands

Middle Pleistocene

Rhine deposits

(Sterksel Fm)

They indicate that water level in the lake reached up to $30 \mathrm{~m}$ above present sea level. The sediments can be seen in the Dutch-German border area of Limburg6

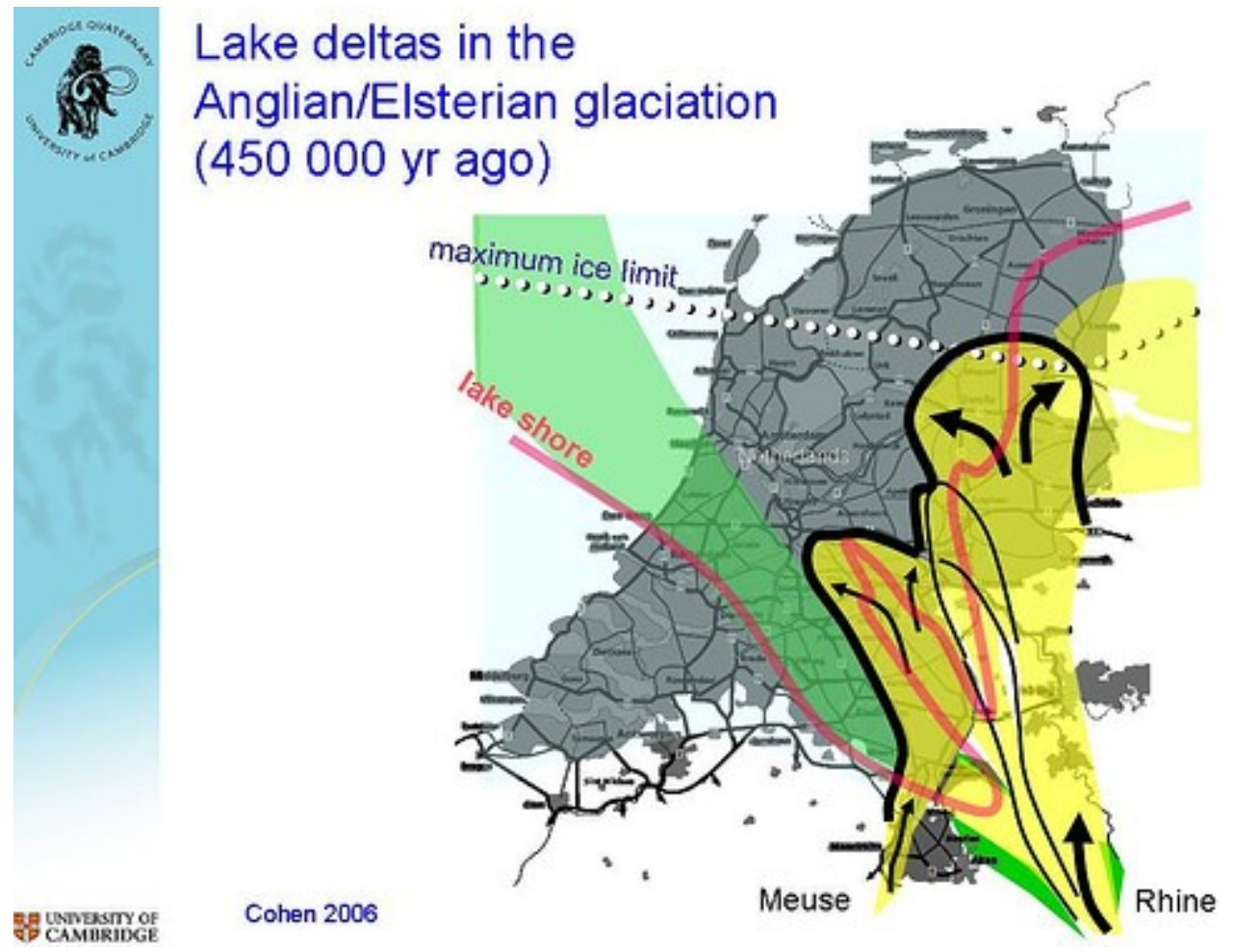




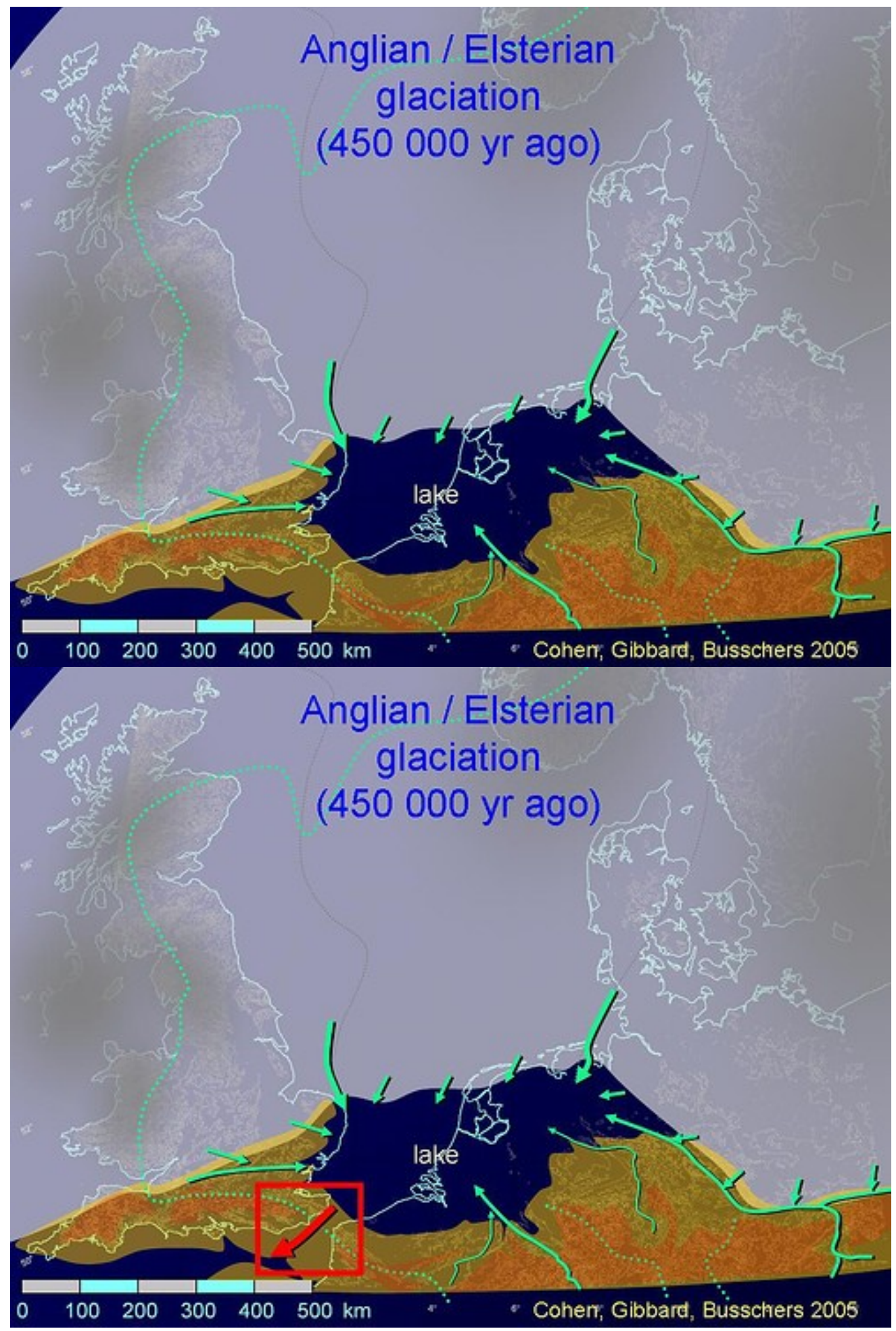

However, you might ask, what was holding up the water to the south? In fact, it was the substantial land barrier, Weald-Artois Anticline, that I mentioned earlier. It was this bedrock barrier that held up the water, and it was this barrier that had to breached if the lake was to drain to the ocean ${ }^{5,6}$. 


\section{Strait of Dover - Pas de Calais}

\section{Strait of Dover - Pas de Calais}

Col ridge height: $\sim 25-30 \mathrm{~m}$

The origin of the narrow waterway that was to become the Dover Strait (Pas de Calais), linking the North Sea to the English Channel has been a point of discussion for over a century ${ }^{5,7}$.

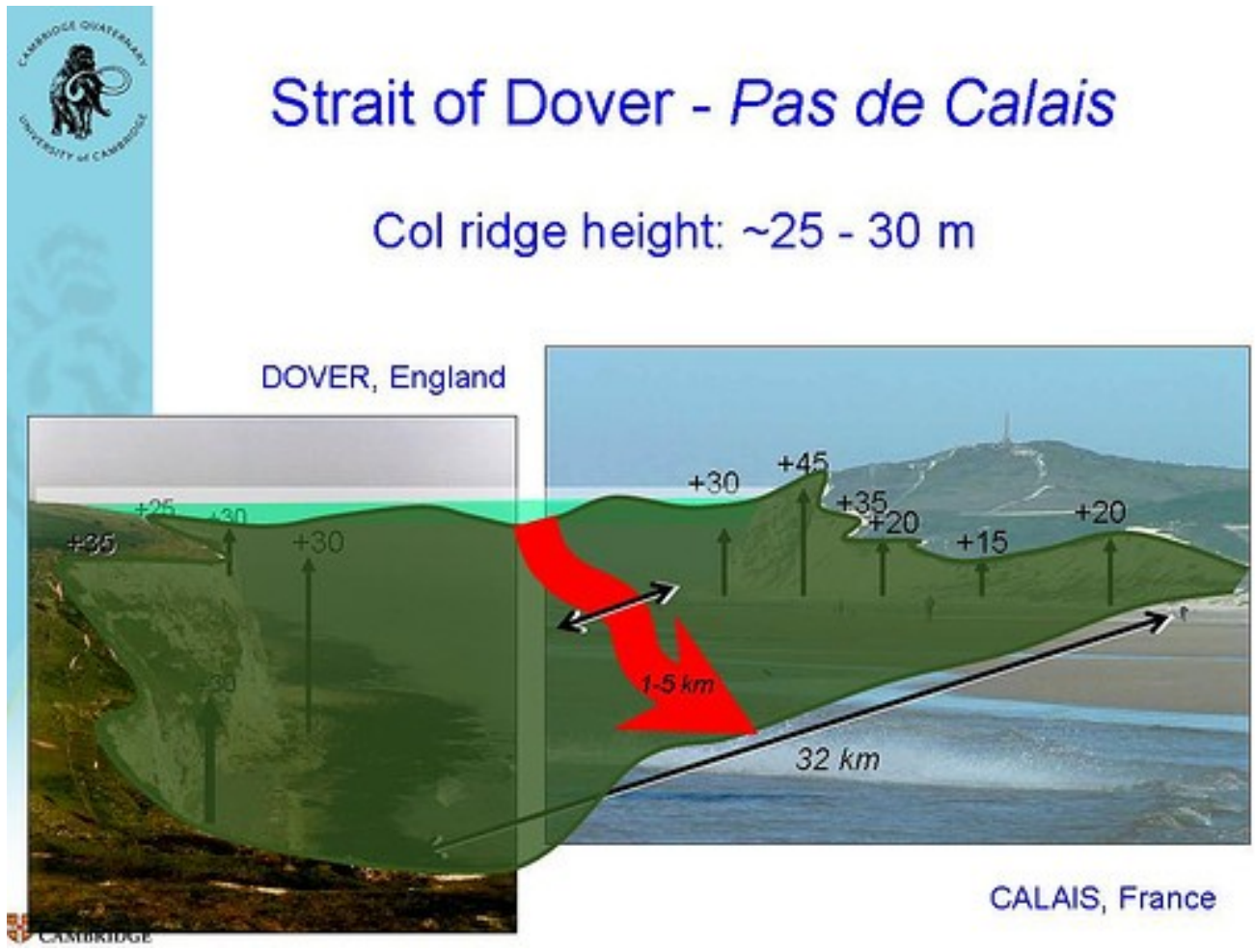


Based on the available evidence, it appears that the lowest point on the pre-existing ridge stood at c. $30 \mathrm{~m}$ above sea-level and this controlled the water-level in the glacial lake. It was this formation of the Dover Strait that was critical to the evolution of the Channel from then onwards to today.

Once the $30 \mathrm{~km}$ wide bedrock barrier was overtopped, the outflow would have quickly become torrential, causing severe erosion.

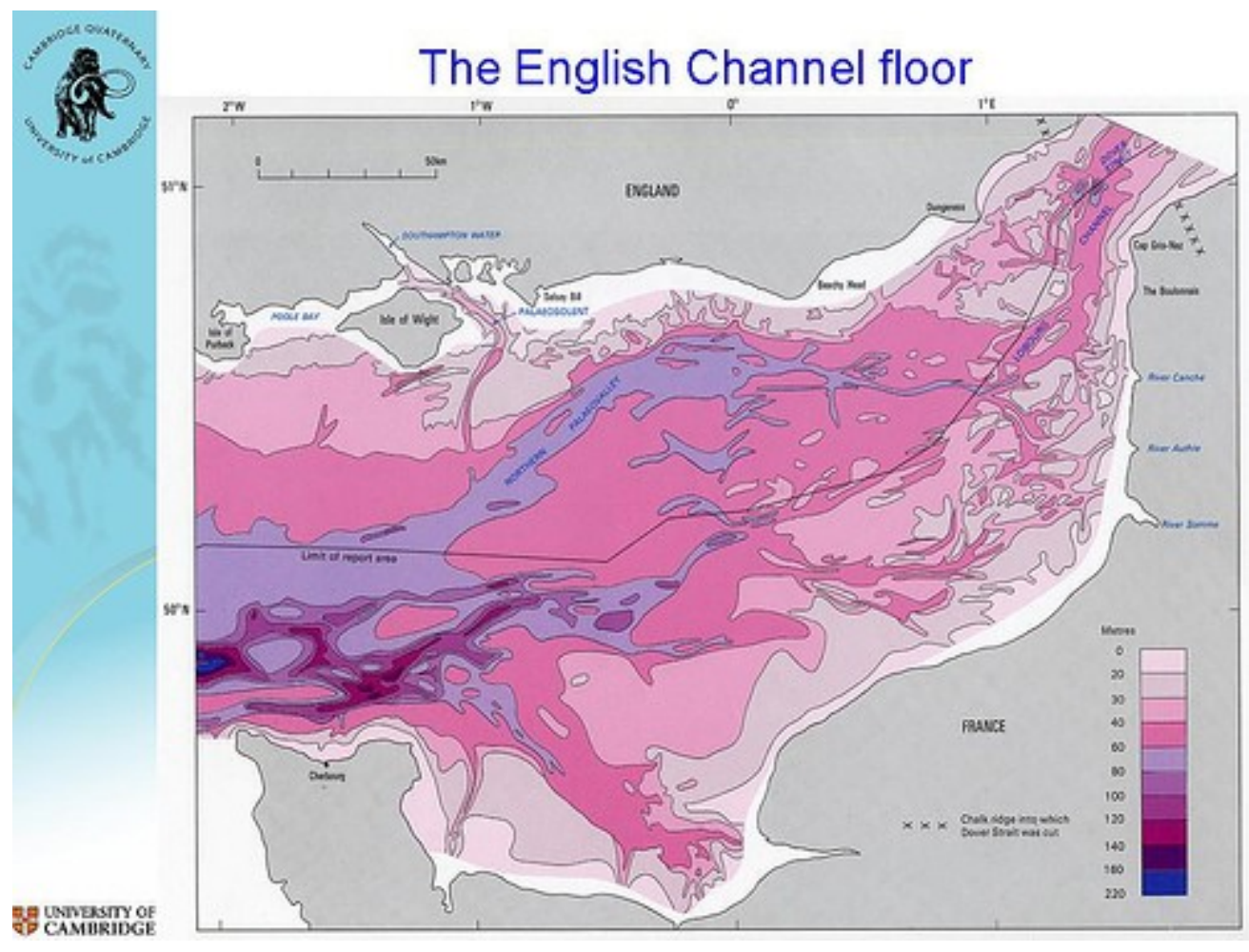

Initially, the overspill followed existing stream valleys into the Northern Palaeovalley. However, the deluge would have quickly overwhelmed these valleys, causing them to be rapidly deepened and enlarged. This was probably the first megaflood identified by Gupta and colleagues in their recent paper $^{1,2,7}$.

The drainage of the lake forced the rivers Thames and Scheldt through the new Dover Strait into the Channel River. However, the Rhine - Meuse rivers returned to the North Sea after the glaciers withdrew and further evolution was halted by a warm-climate (interglacial) event during which sea-level returned to the level similar to today's. 


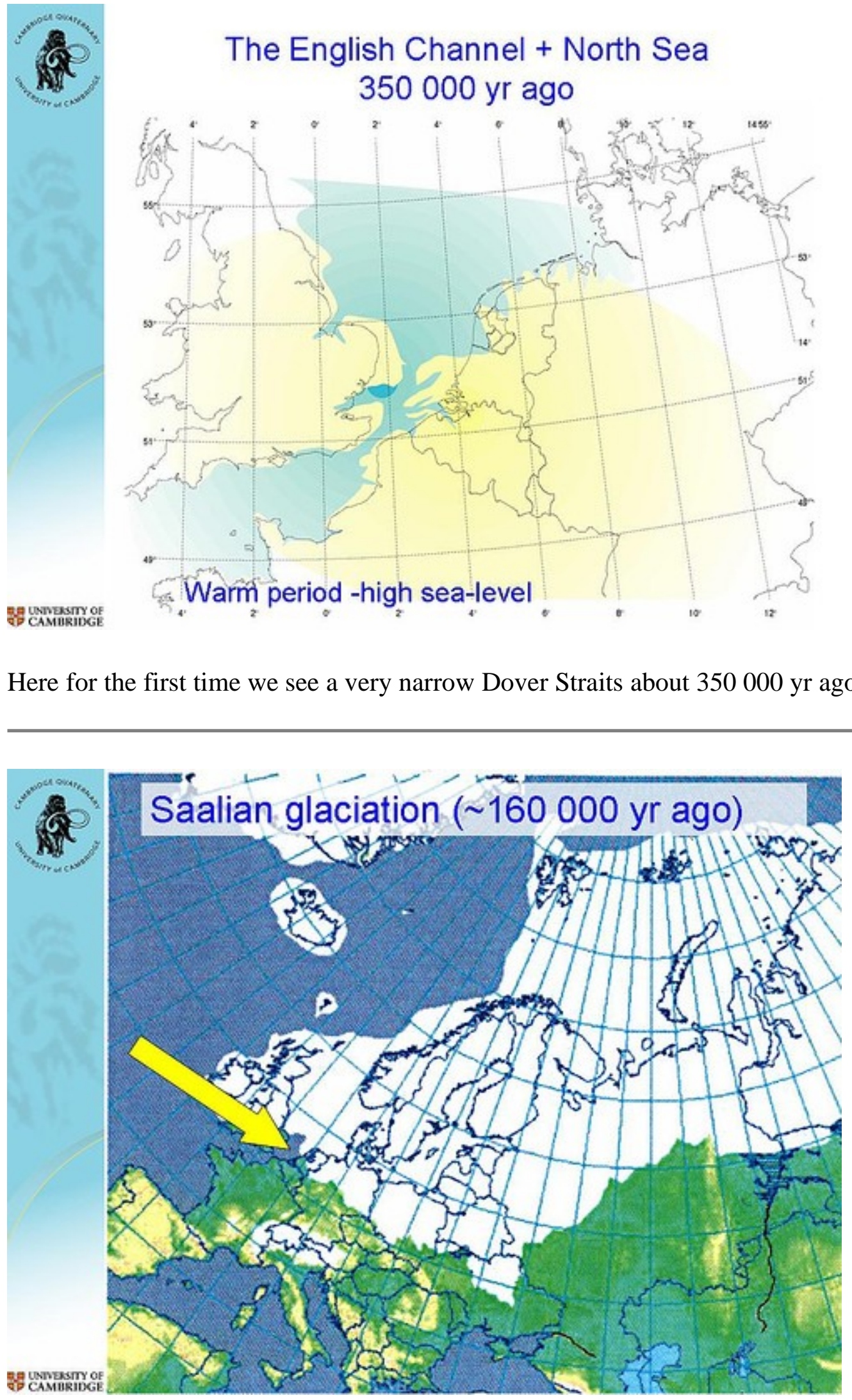


The system continued to evolve for the next $200000 \mathrm{yr}$, but events were brought to a climax some 160000 yr ago when a second major continental-scale glaciation (the Saalian) occurred. This ice sheet again reached central Europe and eastern England. Again it dammed a lake in the southern North Sea, but his time the lake-water level remained close to present sea-level. Recent research shows that in the central Netherlands the major rivers Rhine and Meuse were forced to flow to the SW into an ice-marginal lake ${ }^{2,8}$.
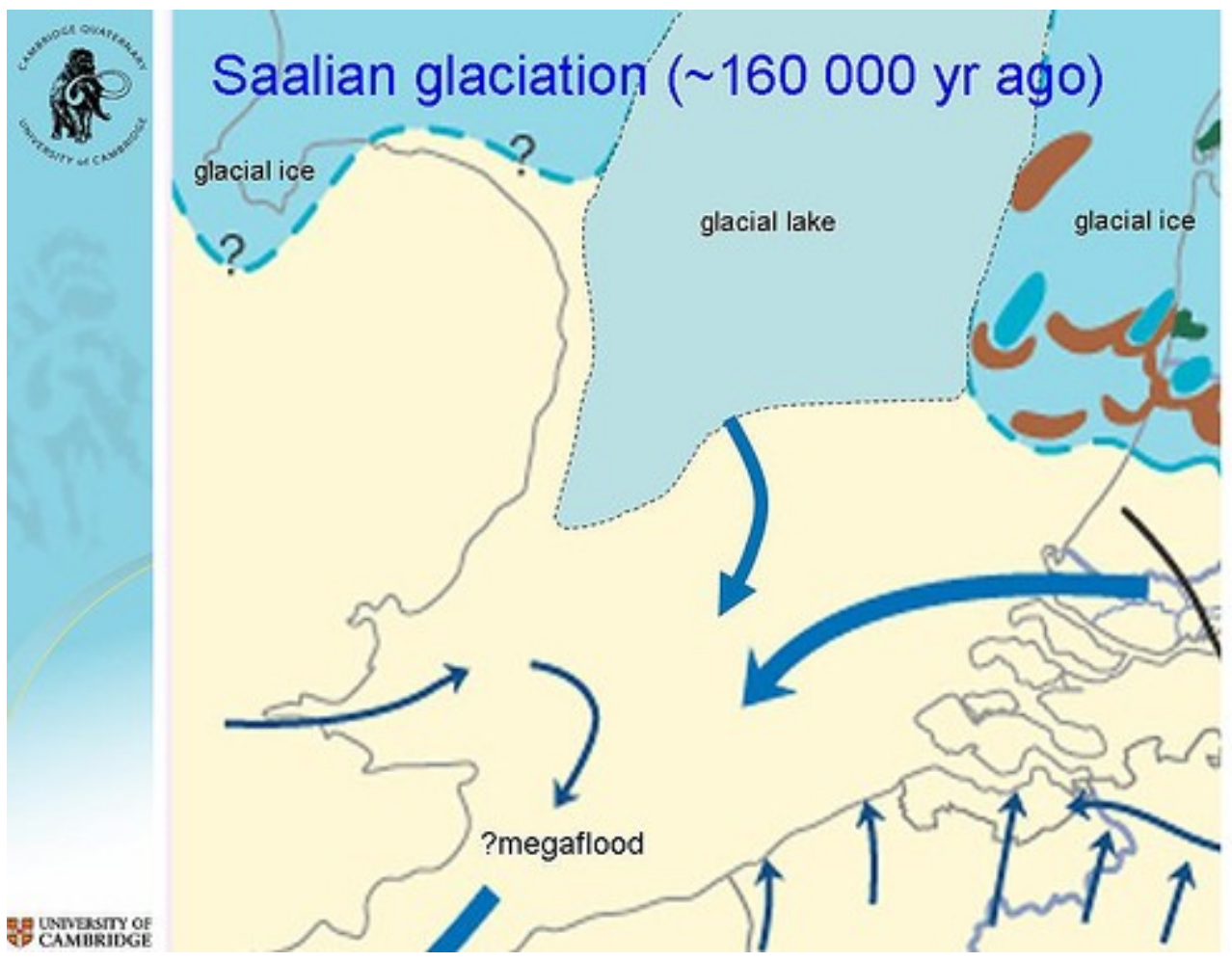

The lake also received water from English rivers.

However, the southern margin of the lake was not at the Dover Strait but at a ridge further north. The failure of this weaker barrier could have been immediate and catastrophic. Its collapse almost certainly released a vast volume of water that immediately became a megaflood that surged through the Dover Strait and thundered on into the Channel-floor valley. This event was the second devastating flood so convincingly demonstrated recently by Gupta and colleagues ${ }^{1,9}$. 


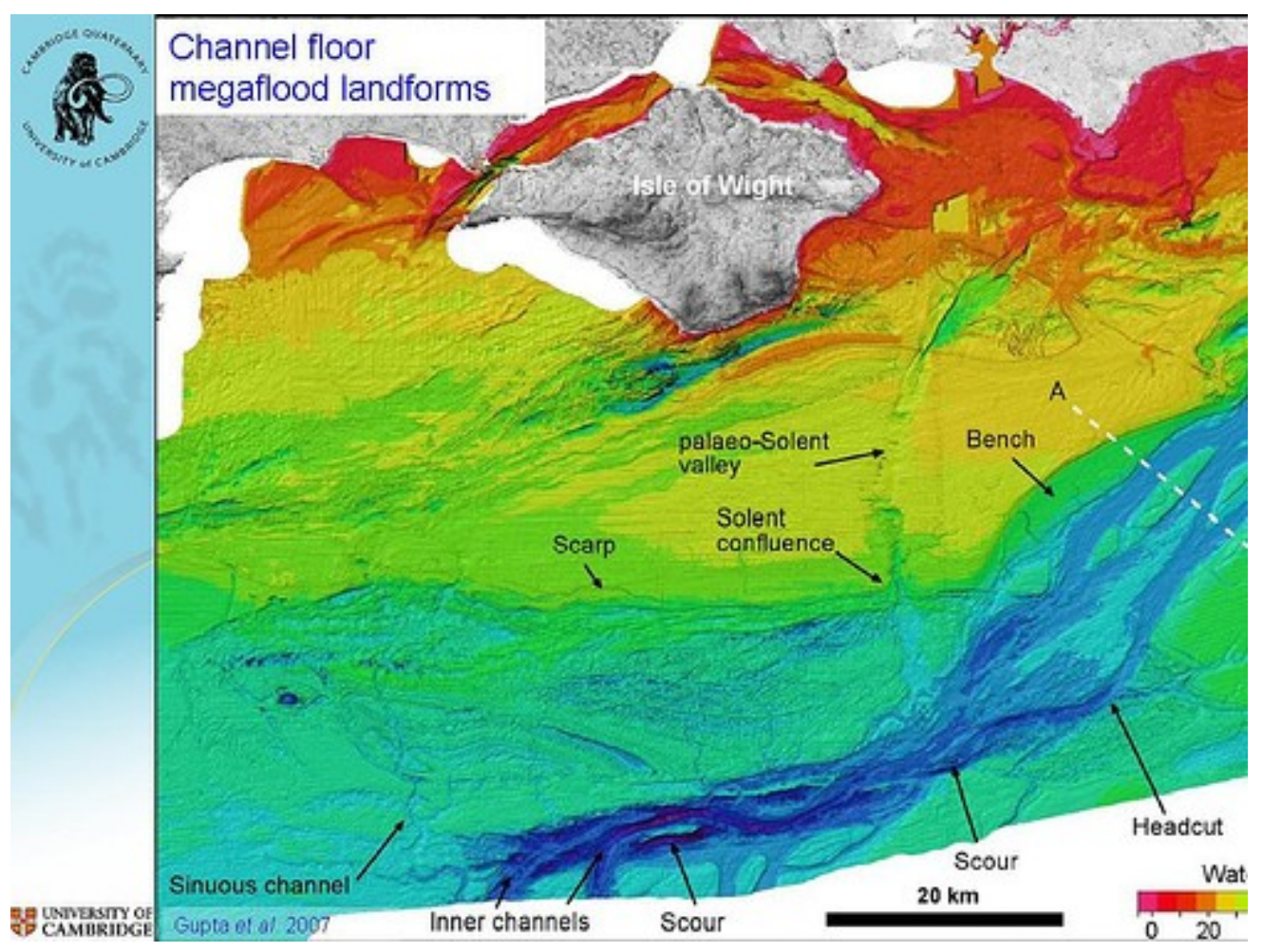

What they found are distinctive features indicating that the valley formed in a catastrophic flooding event, rather than through normal fluvial erosion.

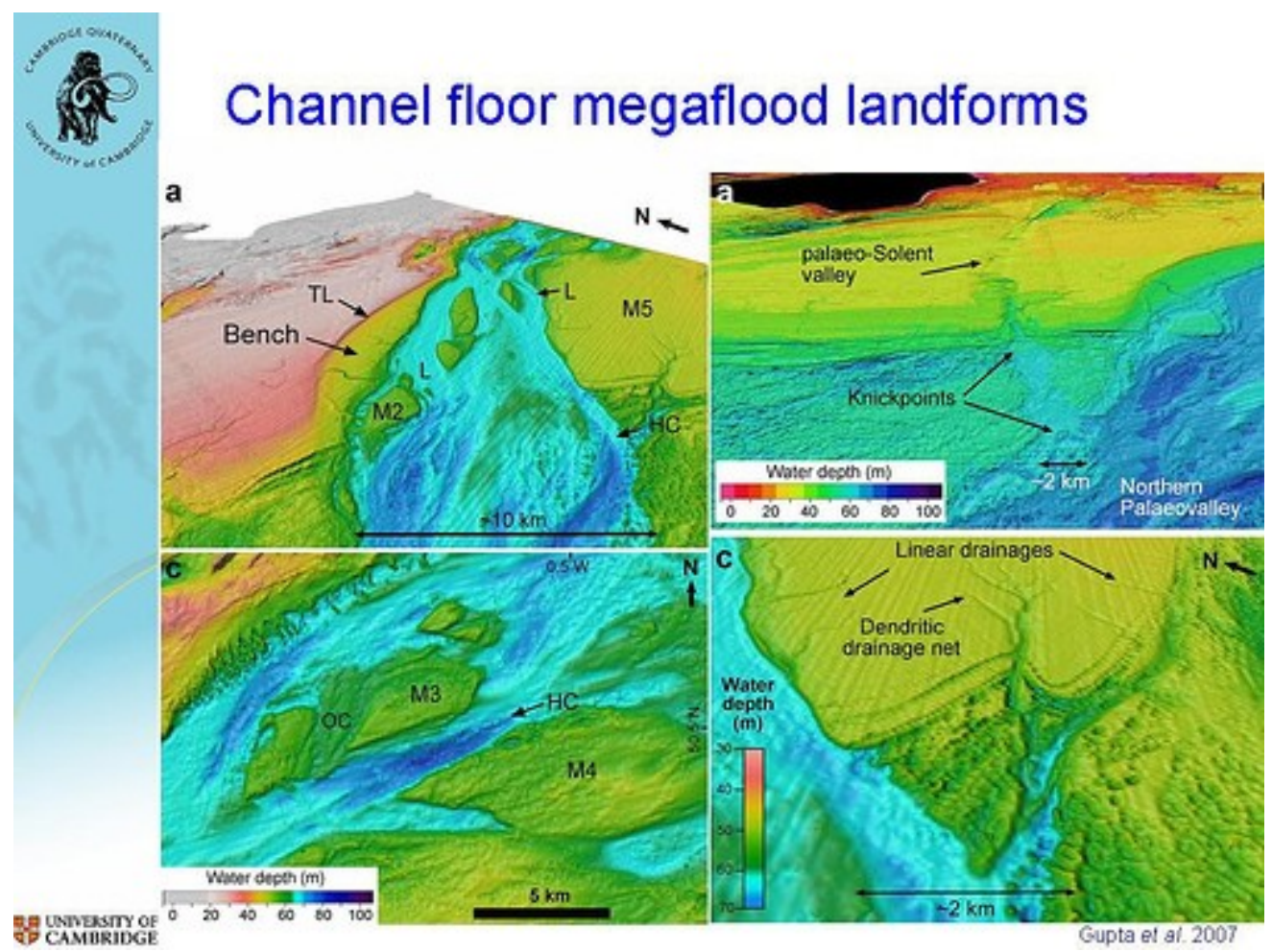


The valley is unusually straight and wide, with prominent, streamlined margins and kilometre-scale grooves; the axis of the valley contains elongate islands characteristic of megaflood erosion; and the palaeo-Solent seems to form a 'hanging tributary' to the main valley, suggesting that the main valley's base level was suddenly lowered. What's more, the specific morphology of a bedrock bench at the valley margin, as well as evidence for an intervening period of normal fluvial erosion, indicate that during the evolution of the Channel at least two megafloods occurred, between 500,000 and 125,000 years ago ${ }^{1,9}$.

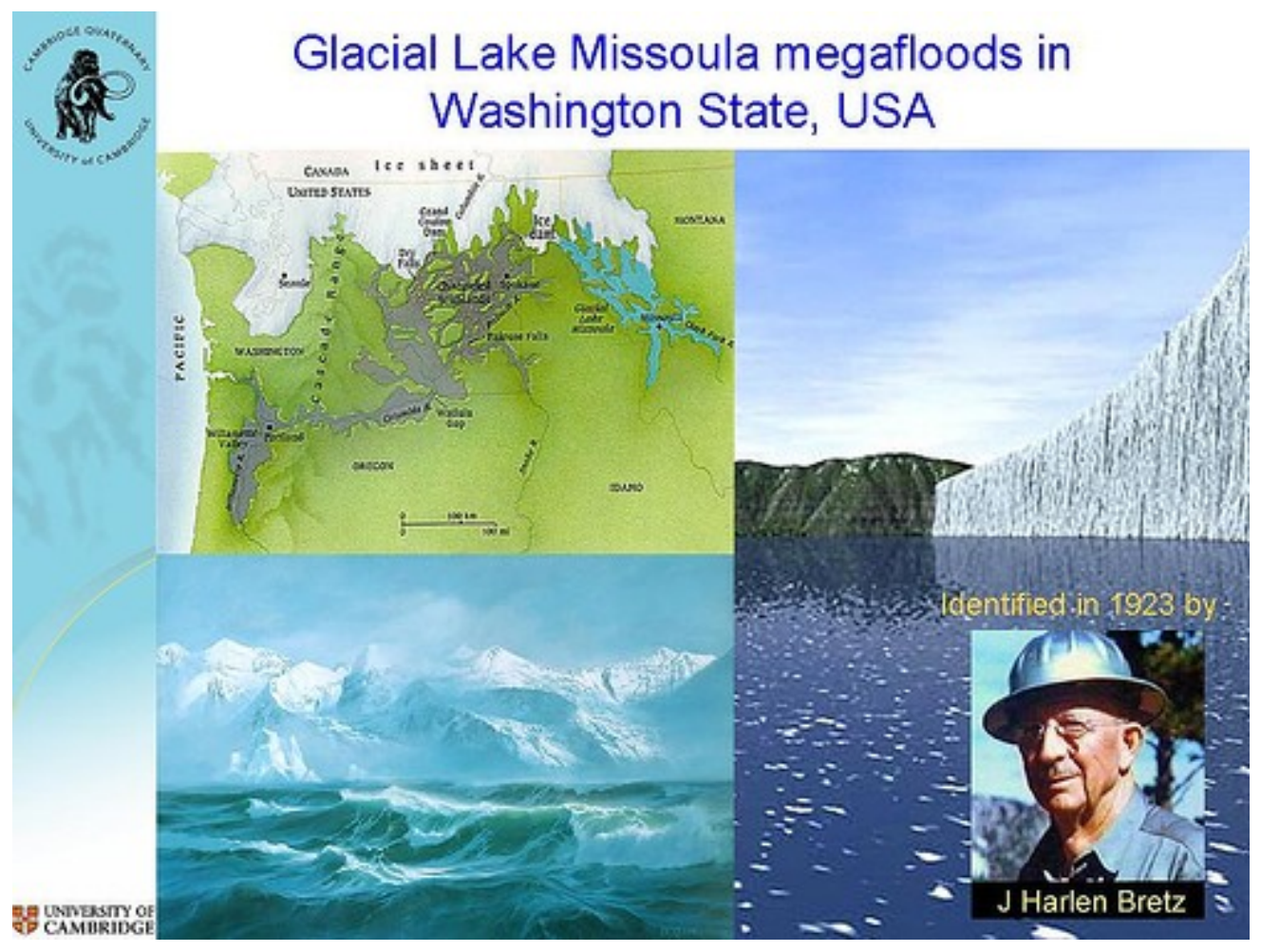

Comparison with the classic evidence for catastrophic megafloods that occurred in the NW USA strongly reinforces the interpretation of the London-based researchers. The classical study of the catastrophic outburst of Glacial Lake Missoula through its ice-dam about 12000 yr ago by the American geologist Bretz was the first where magafloods were identified ${ }^{1,9}$. 


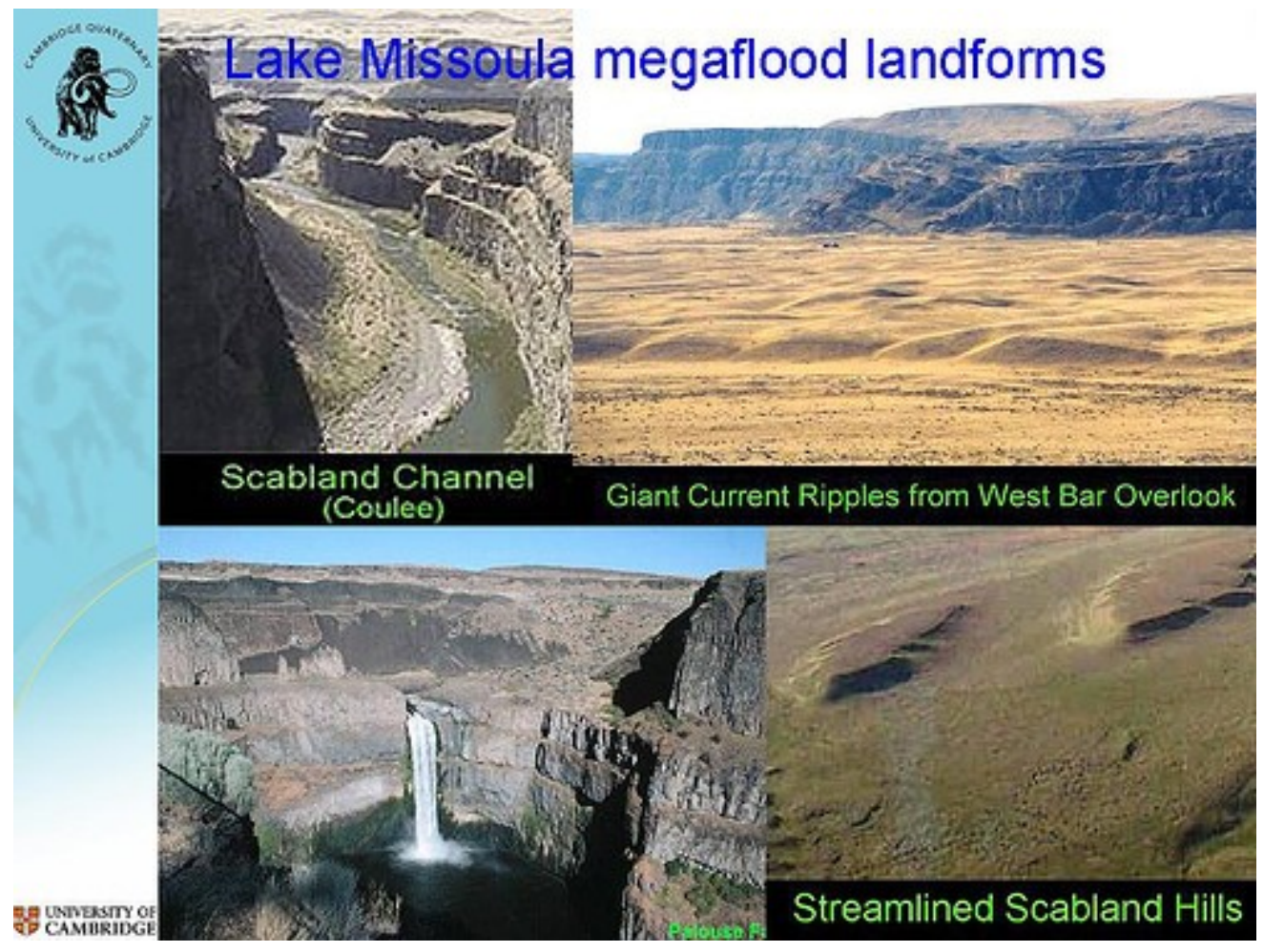

Many of the characteristic landforms identified by Bretz closely resemble those found in the Channel-floor valley.

However, the Channel floods would have been larger and had more profound long-term consequences than those of Lake Missoula. It is no exaggeration to say that the Channel floods are amongst the largest ever identified. 


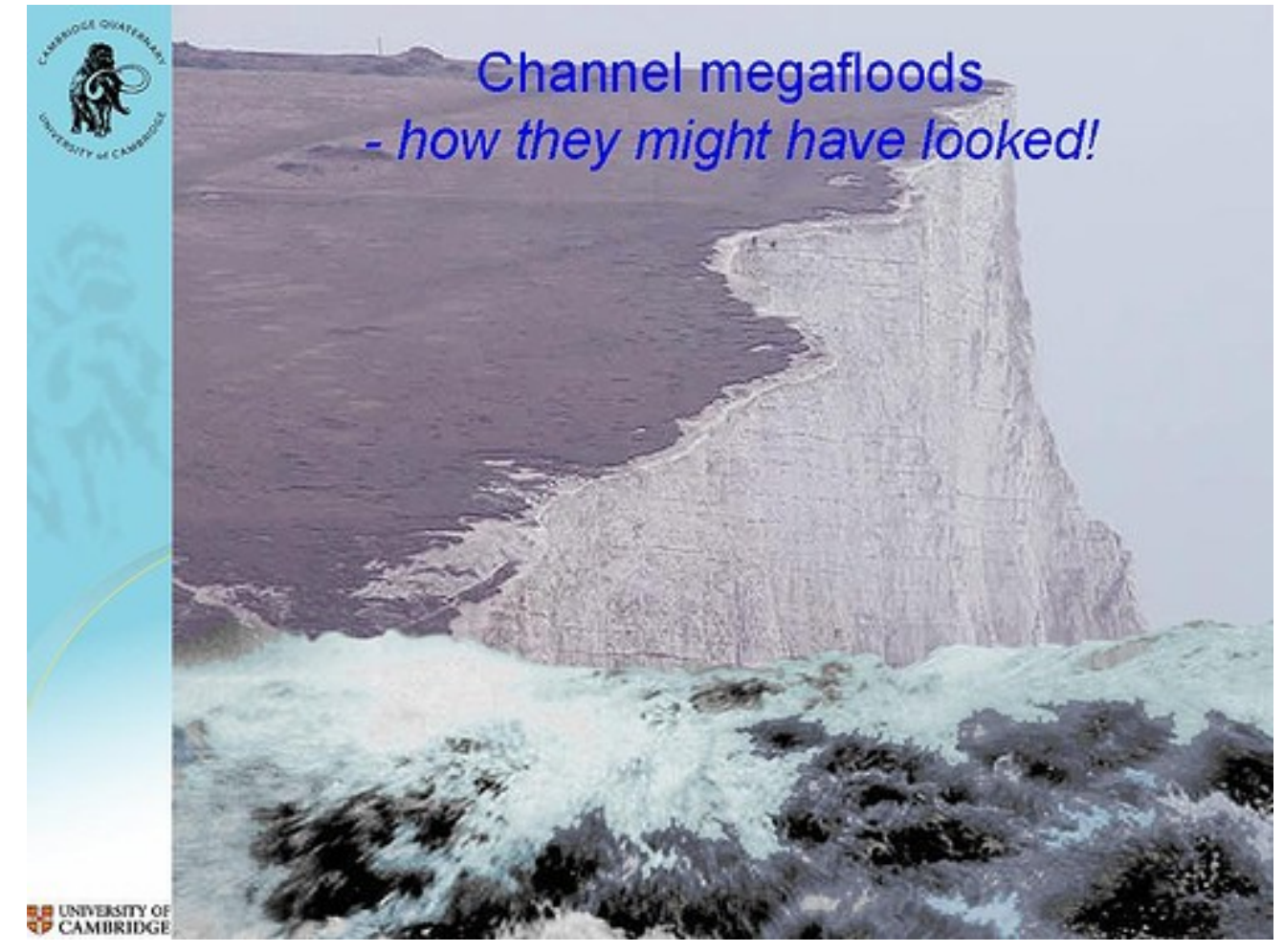

These megafloods sealed Britain's fate; during high sea-level periods it would henceforth be an island ${ }^{1,9}$. One can only imagine what it must have looked like if our forefathers had been there to witness the events!

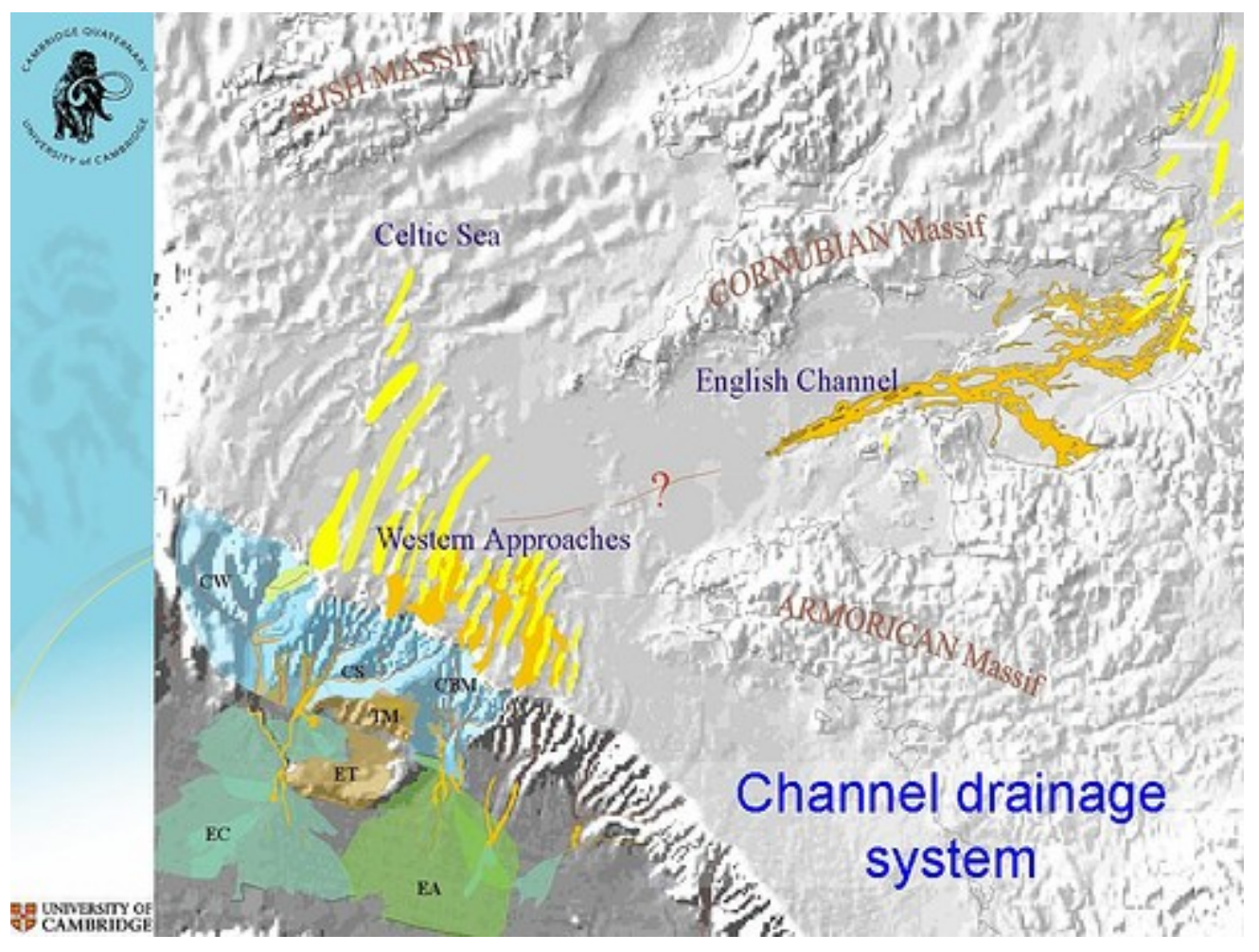


A return to lower sea-levels during the last $100000 \mathrm{yr}$ once more saw the reestablishment of the Channel river system. In this map you can see the full system ${ }^{10}$. In the east there are the valleys on the Channel floor, which pass south-westwards into huge sediment fans that lie on the outer continental shelf and even on the Atlantic deep-ocean floor beyond.

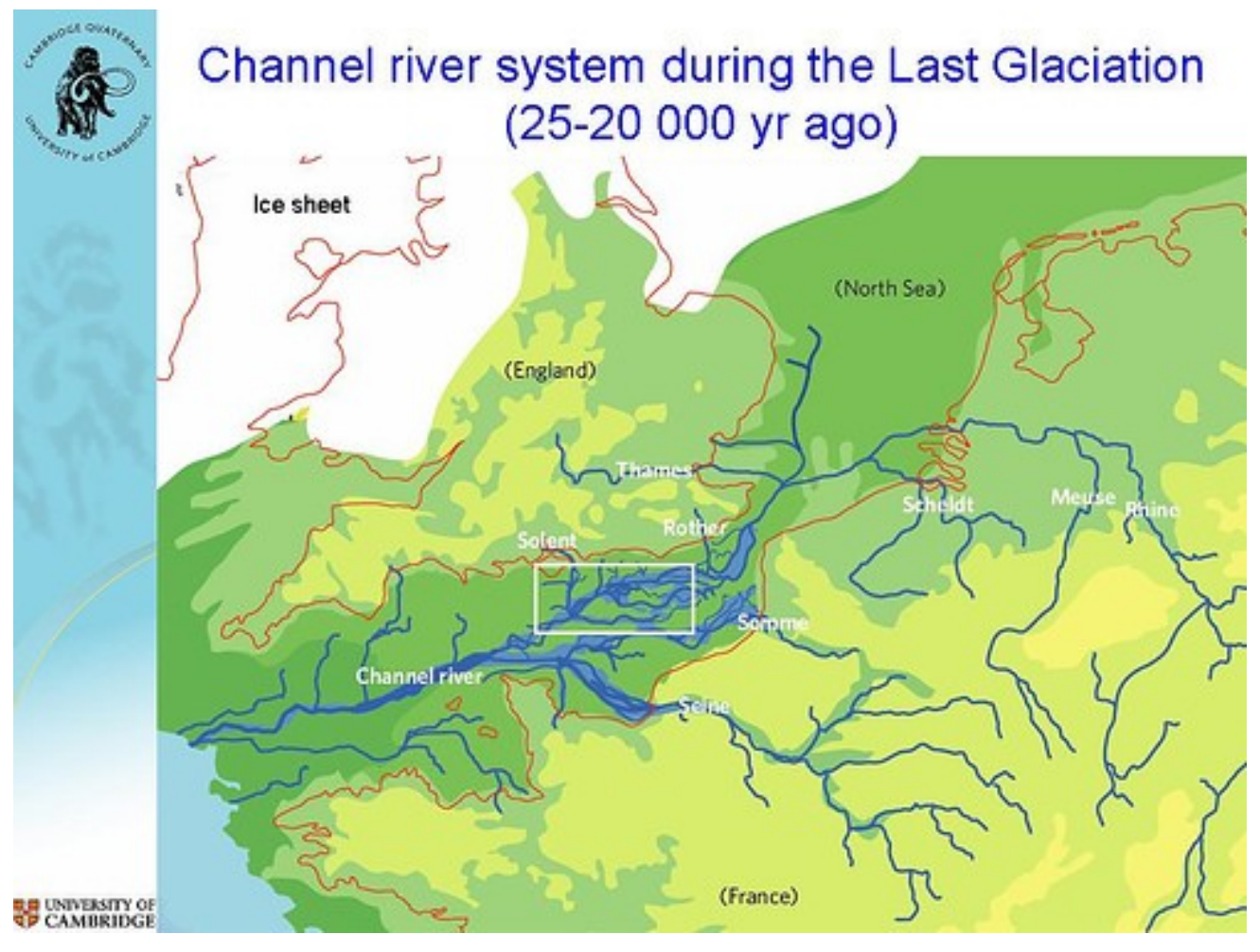

During intervals of low sea level, such as the last glaciation, only $25000-20000 \mathrm{yr}$ ago, the Channel river effectively carries half the drainage of western Europe to the Atlantic Ocean. River and intervening marine erosion ensure that the constriction at the Dover Strait gap was greatly enlarged close to its present form. Moreover, the Rivers Rhine and Meuse had finally been diverted through the Strait to join the Thames, Scheldt, and the Channel rivers, the Seine and Solent, among others ${ }^{2,3,4,9}$. 


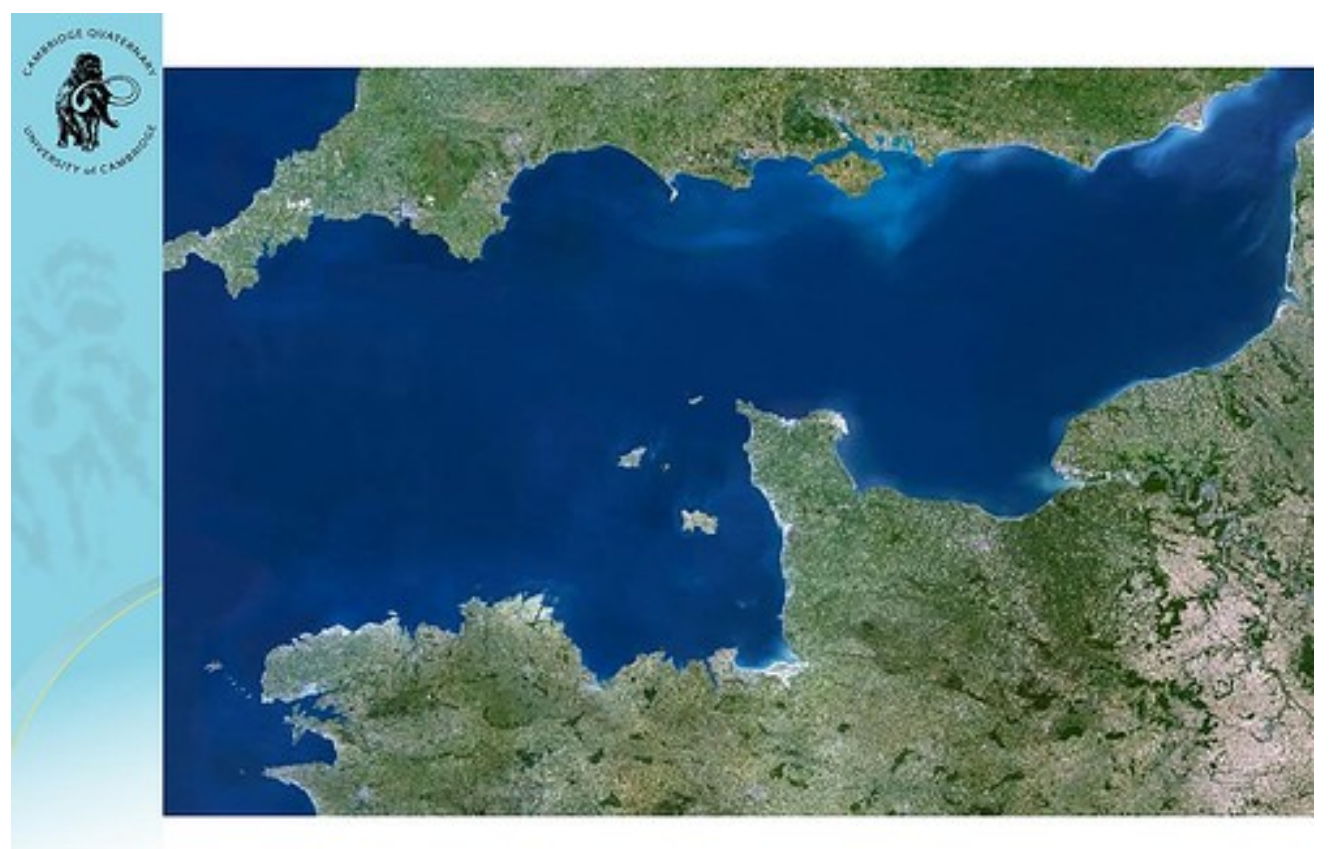

gag GANESTY of

The implications of such striking geographical changes for plant and animal (including human) migration are profound, resulting, among other things, in the impoverishment of the British flora and fauna during warm periods like today, but providing a major routeway during glacial periods. In addition, the virtually instantaneous release of huge volumes of freshwater from the megafloods into the Atlantic Ocean could have triggered changes in ocean circulation which, in turn, could have affected the climate of the whole North Atlantic region'.

Britain's island story began here.

\section{References}

1. Gupta, S., Collier, J. S., Palmer-Felgate, A. \& Potter, G. Nature 448, 342-345 (2007).

2. Gibbard, P. L. Phil. Trans. R. Soc. Lond. B 318, 559-602 (1988).

3. Lericolais, G., Auffret, J.-P. \& Bourillet, J.-F. J. Quat. Sci. 18, 245-260 (2003).

4. Lautridou, J.-P. et al. Bull. Soc. Géol. France 170, 545-558 (1999).

5. Gibbard, P. L. in Island Britain: A Quaternary Perspective (ed. Preece, R. C.) 15-26 (Geol. Soc., London, 1995).

6. Cohen, K. M., Gibbard, P. L. \& Busschers, F. S. in INQUASEQS Meeting Volume of Abstracts (eds Dehnert, A. \& Preusser, F.) 4 (INQUA-SEQS, Bern, 2005).

7. Smith, A. J. Mar. Geol. 64, 65-75 (1985).

8. Busschers, F. S. Unravelling the Rhine Thesis, Vrije Univ., Amsterdam (2007).

9. Gibbard, P.L. Nature 448, 259 - 260 (2007). 
There then followed a discussion: questions and answers below.

Hiro Sheridan: There have been several attempts to reclaim land from the channel, will global warming cause the striat to widen, and if so, in what areas?

PhilG Arida: Hiro, that's an interesting question. I think claiming land in the channel is not a terribly good idea because of marine erosion. Erosion in the Dover area is particularly severe because of the strong current through the channel, and the cliffs are opened by the erosion.

PhilG Arida: As to whether the strait will open: yes, but not significantly, I suspect, because the straits are cut into chalk with very high cliffs and this will certainly retard erosion

CeAire Decosta: Realizing you are not a marine biologist, how would the megafloods have affected sea life species?

PhilG Arida: CeAire, it's highly likely they will have temporarily affected marine life because of the influx of fresh water during the flood itself. However, long term, I suspect the effect will have been somewhat limited

\section{Hiro Sheridan: When was the last time someone could walk to France, before the channel tunnel?}

PhilG Arida: It was possible to walk to France from Britain about 9,000 years ago or possibly a little more, but you would still have got wet feet because of the major river that was there! However, if you prefer to walk from the Netherlands to East Anglia, you could have done that about 8,000 years ago

Hiro Sheridan: Is it possible that there are ancient artifacts on the sea floor, or has everything been buried in sediment?

PhilG Arida: Another good question. Almost certainly there are artifacts on the sea floor because sediment is not accumulating everywhere. Wwe know, for example, that artifacts have been found off the French coast and in the Southern North sea

\section{CeAire Decosta: What kind of artifacts?}


PhilG Arida: Mostly stone tools. Additionally, they are always dredging up bones vertebrate bones, commonly mammoths, bison, that kind of thing. The North Sea floor was definitely occupiable, and was occupied

CeAire Decosta: Now that you've gotten your feet wet so to speak, what do you think of Second Life as a teaching environment? Will you be amenable to doing future presentations here?

PhilG Arida: CeAire, is that an invitation? ;-)

CeAire Decosta: Possibly at some future time!

PhilG Arida: On the question of teaching, I think it's a very powerful tool potentially. When a few of the glitches are sorted out, I do think it holds terrific potential

\section{Hiro Sheridan: When you said the flood was possibly catastrophic, would these settlements have disappeared literally overnight?}

PhilG Arida: Hiro, regarding the settlements, I don't know that there were settlements as such that were contempory with the megafloods. We have no evidence of humans being around to witness them, and therefore, we can't say anything about them.

But naturally if humans had been around, I imagine it wouldn't have been a very pleasant place to be! 